\title{
Locke’s Solid Souls
}

\author{
D. Kenneth Brown \\ Department of Philosophy, California Polytechnic State University, San Luis Obispo, USA \\ Email: dbrown07@calpoly.edu
}

Received July 20 $0^{\text {th }}$, 2012; revised August 24 ${ }^{\text {th }}$, 2012; accepted September $5^{\text {th }}, 2012$

\begin{abstract}
John Locke holds that matter is solid, the soul thinks, and for all we know the soul may be a material substance divinely endowed with a power to think. Though he openly admits to nothing stronger than the bare possibility of thinking matter, Locke grants that what thinks in us occupies a definite spatial location to the exclusion of other souls. Solidity is the quality that prevents other things from occupying a spatial location. Locke's general criterion for identity is spatiotemporal exclusion of other things of the same kind. To meet these conditions for identity, souls must be solid. Although Locke refuses to declare that souls really are material things, taking the solidity of souls to be a condition for their identity is consistent with the following of Locke's other important commitments: 1) nominalism about the essences by which substances are classified; 2) agnosticism about the underlying reality of what supports such "nominal essences"; and 3) the identity of persons is distinct from the identity of any substance. Locke ignores the implication that souls are solid because the solidity of souls is irrelevant to those three aims. Nevertheless he could allow for the solidity of souls without giving up on any of his other important and explicitly held commitments. There is therefore no need for Locke's commentators to refrain from employing solidity in their accounts of Locke's general criterion for identity from fear of attributing to Locke the position that souls would be solid.
\end{abstract}

Keywords: John Locke; Identity; Individuation; Soul; Solidity; Materialism; Substance; Essence

\section{Introduction}

In An Essay Concerning Human Understanding, John Locke speculates that for all we can know, the soul may very well be a material substance, or perhaps a qualitative effect or power of systems of material substances:

We have the Ideas of Matter and Thinking, but possibly shall never be able to know, whether any mere material Being thinks, or no; it being impossible for us, by the contemplation of our own Ideas, without revelation, to discover, whether Omnipotency has not given to some Systems of Matter fitly disposed, a power to perceive and think (IV.iii.6). ${ }^{1}$

Locke holds that we reach beyond our own capacities to know for sure whether or not God saw fit to make matter think. Nevertheless, that matter thinks remains a distinctly conceivable possibility. Though Locke denied that he thought the soul ultimately is a material substance, I shall argue that Locke's discussion of the identity of substances, along with other positions he holds in the Essay, implies that the identity conditions for souls as substances requires souls to be solid. Sure enough, if we accept this conclusion, then souls would have determinate sizes, shapes, and locations-consequences Locke's contemporaries at least, if not Locke himself, would have found repugnant. Even if we accept that Locke's Essay allows for, or even contains, such an argument, we still would have to explain Locke's own insistence that souls are at the very least, most likely immaterial. Yet in spite of protests even from Locke himself, I shall argue that the solidity of souls can find its place in the larger project of the Essay and even shed further light on some of Locke's most central theses concerning the essences of

${ }^{1}$ Citations from Locke's Essay are from (1979) and in the standard form of book, chapter and section. substances and their identity conditions. We will also reach a better understanding of the point of Locke's own apparent denials of this hitherto repugnant conclusion. I have organized this project as follows. I shall first present the textual case for attributing solidity to souls. I shall then present and address other textually based objections to the solidity of souls. In my response to these objections I shall argue that the solidity of souls is consistent with Locke's nominalism about the essences by which substances are classified, as well as his agnosticism about the underlying reality of what supports such "nominal essences.” I shall also argue that Locke's account of the identity of persons renders irrelevant the criteria for the identity of any substance including souls. I will conclude by examining how my proposal of the solidity of souls relates to prominent lines of commentary in the relevant secondary literature which mainly ignore or evade attributing solidity to souls.

\section{The Argument for the Solidity of Souls}

The argument for the solidity of souls arises from Locke's account of the relation of identity in general, wherein he states that

never finding, nor conceiving it possible, that two things of the same kind should exist in the same place at the same time, we rightly conclude, that whatever exists any where at any time, excludes all of the same kind, and is there itself alone (II.xxvii.1)

Here Locke takes spatiotemporal exclusion of all else of the same kind to be a central doctrine in our idea of the identity of anything whatsoever. With respect to substances, Locke thinks that we have ideas of three kinds: God, souls (i.e. "finite spirits"), and bodies (i.e. "matter”) (II.xxvii.2). For any of these 
three kinds of substances, it follows from Locke's general account of identity

that one thing cannot have two beginnings of existence, nor two things one beginning; it being impossible for two things of the same kind to be or exist in the same instant, in the very same place, or one and the same thing in different places (II.xxvii.1).

Locke takes sameness of beginning to follow from the spatiotemporal exclusion of things of the same kind, including souls, since

finite spirits having had each its determinate time and place of beginning to exist, the relation to that time and place will always determine to each of them its identity, as long as it exists (II.xxvii.2).

But Locke also thinks "the same will hold of every particle of matter" (II.xxvii.2). So whether the identity conditions of souls or of matter are in question, the same general criterion for identity applies: the present relation to a determinate spatiotemporal origin determines its identity.

Locke has earlier in the Essay discussed spirits as capable of occupying definite locations given that they can move around:

There is no reason why it should be thought strange, that I make mobility belong to spirit: For having no other idea of motion, but change of distance with other beings that are considered as at rest; and finding, that spirits, as well as bodies, cannot operate but where they are, and that spirits do operate at several times in several places; I cannot but attribute change of place to all finite spirits; (for of the infinite spirit I speak not here.) For my soul being a real being, as well as my body, is certainly as capable of changing distance with any other body, or being, as body itself; and so is capable of motion (II.xxiii.19).

Souls thus have determinate spatial locations for Locke in virtue of their mobility whereby they change their location. By occupying a location in space, souls prevent other souls from also occupying that very same location at the same time. And, these locations can be determined in reference to the locations of bodies.

Earlier in the Essay Locke discusses our idea of that which excludes all else from a given place: solidity. Locke relates solidity to the filling of space when he claims that

[t]he idea of which filling of space is, that, where we imagine any space taken up by a solid substance, we conceive it so to possess it, that it excludes all other solid substances; (II.iv.2).

Solidity is thus the idea by means of which we distinguish empty space from space occupied by something (II.iv.3). And it is just such an occupation of space at a time that a determination of identity requires. This statement about solidity and spatial exclusion would apply to any solid substance. Here the point concerns what we attribute to something that does exclude others from its space: by virtue of that spatial exclusion, it is solid.

The following argument for the solidity of souls results from drawing a plain inference from Locke's general account of identity and the function of the idea of solidity:

1) The identity conditions of substances require them to occupy some determinate place at some time to the exclusion of all other substances of the same kind.

2) To occupy a determinate place to the exclusion of other things of the same kind requires it to be solid.

3) Thus, the identity conditions of substances require substances to be solid.

4) Souls are substances.
5) Thus, the identity conditions of souls require souls to be solid.

The logic of this argument is plain. Locke is committed to 1) and 2) about identity and solidity for substances, so Locke must be committed to 3). Locke asserts 4), so he must accept 5). The conclusion of this argument relates solidity to souls by means of their identity conditions, so to clarify the meaning of the conclusion some further remarks about the relation of identity are in order.

Locke's principle of identity is "existence it self” (II.xxvii.3). So, if this argument is sound, to deny that souls are subject to the relation of identity is to deny souls their existence. To speak of the identity of a soul is just to relate a soul to itself and distinguish it from things other than itself; ${ }^{2}$ and that just is what it is for a soul to exist. Locke considers there to be one sort of substance which cannot be subsumed within a spatiotemporal framework for its identity, and that is God. But, other substances, having discrete particular instances, need criteria for their diversity in order to fix on them as something whose identity can then be considered. So, we can understand the argument under consideration as pertaining only to "finite" substances. That is, the argument applies to substances that admit of multiple token instances of a common type. The spatiotemporal framework constitutes the conditions for distinguishing amongst such token instances of the same type. God can thus be diverse from other substances by means of the spatiotemporal framework the other substances require for determinations of their identity. ${ }^{3}$ In this way, relating a soul to itself employs a spatiotemporal framework, and it is that framework that sets that soul apart from all other things diverse from it. As I have interpreted it, solidity is just the universal criterion for spatiotemporal exclusion. Solidity would then be the property a substance must have to be set into a relation of identity, given that there are discrete instances of the same type of substance. It is in this sense that we should understand the identity of a substance to be its existence, and to require a property, viz. solidity, to determine that existence.

\section{Some Objections}

One might object to the argument for the solidity of souls on grounds that it requires one to apply very selective attention to Locke's account of the idea of solidity. This line of objection would be advantaged were it to be endorsed by Locke himself, and there might be some reason to think it is. Locke's account of solidity is framed by his attempt to explain how we find our idea of solidity in sensation. Sensation supplies our ideas of external objects, while reflection provides us with ideas about that which concerns thinking (II.i.5). The idea of solidity, Locke claims, arises exclusively from touch, and is the idea most constantly received from sensation (II.iv.1). He further proclaims that of all our other ideas, solidity "seems the idea

\footnotetext{
${ }^{2}$ Identity is the relation by which things are individuated. Though Locke himself does not formulate his points in terms of individuation, oftentimes he expresses his positions about identity by means of discussions of the application of the relation of identity to the individuation of things.

${ }^{3}$ In his proof of the existence of God, Locke distinguishes God from matter without invoking solidity or spatiotemporal exclusion as criteria. Rather, he concerns himself with distinguishing between "cogitative" and "incogitative" beings (IV.x.9), and assigns eternity and activity only to cogitative beings (IV.x.10-11). As we will see below, when Locke directs his attention to the presence or absence of "cogitation", he is neutral about what other properties a cogitative being may possess.
} 
most intimately connected with, and essential to body” (II.iv.1), and continuing with this remark, he strengthens his commitment to the claim that solidity is

no-where else to be found or imagined, but only in matter. And though our senses take no notice of it, but in masses of matter, of a bulk sufficient to cause a sensation in us; yet the mind, having once got this idea from such grosser sensible bodies, traces it farther; and considers it, as well as figure, in the minutest particle of matter that can exist: And finds it inseparably inherent in body, wherever or however modified (II.iv.1).

Even in the passage that most clearly supports the notion that solidity is the idea of something occupying space, Locke explicitly speaks only of body as having this feature:

This is the idea which belongs to body, whereby we conceive it to fill space. The idea of which filling of space is, that, where we imagine any space taken up by a solid substance, we conceive it so to possess it, that it excludes all other solid substances; [...] This idea of it the bodies which we ordinarily handle sufficiently furnish us with (II.xxvii.2).

The whole chapter on solidity is part of his longer discussion of the ideas we receive from sensation, and Locke repeatedly informs us that what we sense are bodies. Locke's commitment to the association of solidity with material substances runs quite deep since, according to Locke, solidity is a primary quality of body. As such, our idea of solidity is inseparable from our idea of any body no matter what state that body may be in (II.viii.9). Further, our idea of solidity is a resemblance of what actually is in a body itself. Given Locke's own steadfast insistence that solidity is an idea whose proper association is with bodies, it seems that he should somehow deny the solidity of souls. Locke seems to do so when he explains how, when forming our idea of the soul, we take care not to ascribe solidity to the soul:

For putting together the ideas of thinking and willing, or the power of moving or quieting corporeal motion, joined to substance of which we have no distinct idea, we have the idea of an immaterial spirit; and by putting together the ideas of coherent solid parts, and a power of being moved, joined with substance, of which likewise we have no positive idea, we have the idea of matter (II.xxiii.15).

Locke later says that this collection of ideas in our complex idea of spirit is peculiar to immaterial souls. He says the same of the ideas he has here ascribed to material bodies. But, Locke does explicitly ascribe existence, duration, and mobility both to souls and to bodies (II.xxiii.18). ${ }^{4}$ Although our ideas of souls and bodies do have some features in common, solidity is not one of them. The issue at stake here is whether bodies are solid things that occupy an expanse of space, while souls might be more like a concentration of various powers into a point with no spatial volume. ${ }^{5}$ The ideas of space and solidity are different ideas. The objection at stake here asserts that the collection of

${ }^{4}$ As noted above, Locke considers their sharing of mobility notable enough to discuss, while taking their sharing of duration and existence to be uncontroversial (II.xxiii.19-21).

${ }^{5}$ Locke employs an analogy with geometrical points to motivate the attribution of change of place to spirits: "if a mathematician can consider a certain distance, or a change of that distance between two points, one may certainly conceive a distance, and a change of distance between two spirits: And so conceive their motion, their approach or removal, one from another" (II.xxiii.19). This passage does not commit Locke to the position that souls exist at unextended spatial points. Instead, the conception of change of place requires only the ideas that are included in the notion of a spatial point. And, those ideas are also in the complex idea of spirit. So, spirits can change place. ideas in the complex idea of spirit can include existence, duration, and mobility and spatial location, but need not and does not include solidity.

As it stands, this is a fairly devastating objection to the argument that souls are solid. For if this objection succeeds, we would attribute solidity to souls quite in defiance of Locke's insistence that solidity applies only to material bodies. This line of objection would restrict premise 2) only to bodies:

$2^{*}$ For a body to occupy a determinate place to the exclusion of other bodies requires the body to be solid.

Of course, this would allow a body to be solid while allowing a non-solid soul to occupy the place delimited by the body's solidity. This modification of 2) into $2^{*}$ ) thereby allows for the cohabitation of souls and bodies, but with the metaphysical price of eliminating criteria for distinguishing souls from each other. If Locke is committed to 2), he is committed to the solidity of souls. If he rejects 2 ) in favor of $2^{*}$ ), Locke can reject the solidity of souls. To determine whether Locke would prefer 2) or $2^{*}$ ), that is, to determine whether Locke accepts or rejects the argument for the solidity of souls, we need to consider more carefully Locke's account of the distinction between solid bodies and immaterial souls.

\section{Solidity, Thinking, and the Nominal Essence of Spirit}

Locke's published disputes with Edward Stillingfleet, the Bishop of Worcester, offer a good source of developments of his positions on the status of our knowledge of the immateriality of the soul. Amongst other attacks on Locke's Essay, Stillingfleet accuses him of, at the very least, providing a basis for the doctrine that the soul is a material substance. Locke's replies to Stillingfleet ${ }^{5}$ are duly rife with Locke's views on this topic. He regularly states that the idea of spirit simply is the idea of that substance which thinks regardless of any other qualities it may have. Stillingfleet objects insisting that a thinking substance cannot under any circumstances be solid. Locke replies:

Against this your lordship will argue, that by what I have said [in IV.iii.6 of the Essay] of the possibility that God may, if he pleases, superadd to matter a faculty of thinking, it can never be proved that there is a spiritual substance in us, because upon that supposition it is possible it may be a material substance that thinks in us. I grant it; but add, that the general idea of substance being the same every where, the modification of thinking, or the power of thinking joined to it, makes it a spirit, without considering what other modifications it has, as whether it has the modification of solidity or no. [...] [S]ubstance, that has the modification of solidity, is matter, whether it has the modification of thinking or no (Letter, 33).

When clarifying the position he held on this issue in the Essay, Locke plainly states that the idea of spirit does not necessarily exclude solidity. Nevertheless, any thinking substance is as such a spiritual substance. Likewise, any solid substance is as such a material substance. Locke thus grants the possibility that the soul is solid in the same sense that matter is solid since he is granting the possibility that the soul simply is a material substance. So, as we noted earlier, the conclusion to the argument for the solidity of souls implies that souls are material substances. And, thus far, we see that Locke denies neither the possibility that this conclusion is true nor that it is entailed by his other commitments.

\footnotetext{
${ }^{6}$ All references to Locke’s replies to Stillingfleet are to Locke (1823).
} 
Locke's reason for refusing to deny the possibility that souls are solid (or rather that matter thinks) is simple: there is no contradiction in such a supposition. ${ }^{7}$ Again in reply to Stillingfleet Locke says:

For I only say, that it is possible, i.e. involves no contradiction, that God, the omnipotent immaterial spirit, should, if he pleases, give to some parcels of matter, disposed as he thinks fit, a power of thinking and moving; which parcels of matter, so endued with a power of thinking and motion, might properly be called spirits, in contradistinction to unthinking matter. In all which, I presume, there is no manner of contradiction (Second Reply, 482).

Though thought and solidity are very different ideas, Locke finds no contradiction between them. But, he insists that he has gone only so far as to allow the mere possibility that souls are solid. Locke admits this possibility by refusing to deny that God has the ability to grant the power of thought to any substance whatsoever. After yet again asserting that God could give to matter a power of thought, he adds that his own capacity to conceive of God as having this ability "is the utmost I have said concerning the faculty of thinking in matter" (294).

Echoing this last remark much later in his Second Reply, Locke provides us with a thought experiment to show how conceiving of a solid substance as thinking would not "confound the idea of matter with the idea of spirit” (460). We are to imagine that

God creates an extended solid substance, without the superadding any thing else to it, and so we may consider it at rest: to some parts of it he superadds motion, but it has still the essence of matter: other parts of it he frames into plants, with all the excellencies of vegetation, life, and beauty, which are to be found in a rose or a peach-tree, \&c. above the essence of matter in general, but it is still but matter: to other parts he adds sense and spontaneous motion, and those other properties that are to be found in an elephant. Hitherto it is not doubted but the power of God may go, and that the properties of a rose, a peach, or an elephant, superadded to matter, change not the properties of matter; but matter is in these things matter still. But if one venture to go on one step further, and say, God may give to matter thought, reason, and volition, as well as sense and spontaneous motion, there are men ready presently to limit the power of the omnipotent Creator, and tell us he cannot do it; because it destroys the essence... (460).

For Locke, to "superadd" a quality to a substance is to add to a substance something not contained in its essence. In this thought experiment, motion, vegetative life, sense, spontaneous motion, thought, reason, and volition are each successively superadded to what was originally merely an extended solid substance conceived as being at rest. All of these superadded qualities are distinct from extension, solidity, and rest so that to conceive of such bare matter as having any of these qualities, we must conceive of them as other than or not entailed by extension, solidity and rest. Thus the superadded qualities are distinct from other qualities inconceivable apart from extension, solidity or rest. Shape is a quality that is not superadded to bare

${ }^{7}$ Of course Locke also holds that the ideas of substances are inherently confused in virtue of including in them the confused notion of substratum or unknown support for the qualities of the substance. However, what is at stake here concerning the contradiction is not anything that invokes the confused notion of support for qualities, but instead whether the collection of qualities includes some that contradict others. For instance, a moving thing at rest would be a contradiction regardless of what else might be obscure about the idea of the thing. matter, as the absence of shape would contradict the bare notion of matter contained in the essence of solid extension. Motion, however, goes beyond solid extension such that conceiving a solid extended substance to be moving is to conceive of something more than a mere solid extended substance. Solid extension and solid moving extension are different in that the latter has a quality (viz. motion) superadded to what's in the former (viz. only solid extension), but this difference in no way renders the conception of the one incompatible with the conception of the other. Instead, what we have here are two ways of conceiving of solid extension. One way is only in virtue of solid extension itself, and the other way is of solid extension modified in some other additional way.

We are perfectly able to conceive of substances as having additional qualities incomprehensibly, yet undeniably, associated with them. For Locke, gravity serves as just such an example of a quality superadded to matter. Gravitational attraction is thereby quite different from the transfer of motion by impact. Solidity implies impenetrability, and, Locke thinks, thus affords us an easy conception of interaction of bodies by impact. However, a primitive attractive force in no way is implied by solidity and extension alone. Yet, he acknowledges that given Newton's physics, a force of gravity is undeniably associated with matter. Thus gravitational attraction is yet another instance of a superadded power not otherwise included in the mere notion of a solid extended substance (Second Reply, 463, 467-468). Locke asks whether any of the subsequent items on the list of superadded qualities from his thought experiment confound the notion of extended solid substance. Our inability to conceive of the basis for the power of a more primitive notion of extended solid substance to move, live, sense, or think is completely remote from our comprehension, but this ignorance in no way implies a contradiction between the ideas of the superadded qualities and of the more primitive substance that receives the power to sustain the superadded qualities.

In the correspondence with Stillingfleet Locke has greatly elaborated on his commitment to the possibility that souls are solid substances. The argument for the solidity of souls goes farther than just the mere possibility that souls are solid. Since for Locke the identity of souls is the same as the existence of souls, (Essay, II.xxvii.3), for souls to be solid, they would be material substances. And, according to Locke, "from thinking experimented in us, we have a proof of a thinking substance in us, which in my sense is a spirit” (Letter, 32). So there are souls insofar as there are thinkers. Despite the certainty of the existence of thinking substance, the controversy with Stillingfleet is over whether or not thinking substance is immaterial. Locke further claimed

if your lordship means by a spiritual an immaterial substance, I grant I have not proved, nor upon my principles can it be proved, [...] that there is an immaterial substance in us that thinks" (Letter, 33).

The flip side of this claim is that Locke's principles also cannot prove that the thinking substance in us is material. Given his caution about drawing unwarranted conclusions about the necessity of the immateriality of the soul, has Locke in the Essay provided for a conclusion that his replies to Stillingfleet do not allow us to draw?

In Book III of the Essay, Locke draws some crucial distinctions concerning substances and essences. A nominal essence consists of ideas grouped together by a supposition that something independent of them unites them into one thing. That is, 
when we form an idea of the soul as that which thinks, we conjoin ideas of various ways of thinking by supposing that something we call a soul really does unite the various thoughts into a single thing. In doing so, we have given the names "soul" and "spirit" to that unified conjunction of ideas. Those ideas thus form the nominal essence applicable to the soul/spirit. But, these names refer not only to the ideas that form a nominal essence, but also to a supposed but unknown thing that we take to be the real bearer of the power of thinking. If this supposed bearer of the powers contained in the nominal essence really exists, its real nature is its real essence. So, whatever really thinks in us has a real essence that is responsible for thinking. Locke thinks that our ideas of substances are nominal essences (III.vi.11). His resistance to Stillingfleet's concerns about the real nature of spiritual substance rests largely on the conviction that the real essences of substances are unknown (III.vi.9). So, Locke's denial that his principles imply anything about the materiality or immateriality of spirit is genuine since Locke takes Stillingfleet's concerns to be about the real essence of spirit. What's at stake in the argument for the solidity of souls is whether to include solidity in addition to the power of thinking in the nominal essence of spiritual substance. It is important to see that Locke's discussion of our ideas of spiritual and material substance should be subsumed under his account of such nominal essences, and not real essences.

As we saw in his replies to Stillingfleet, Locke claims that it is indisputable that we have an idea of that in us which thinks. But nevertheless we lack an idea of what it is in us that thinks apart from that it thinks. So we therefore lack any basis for any claims about the real essence of what thinks apart from that it thinks. On these grounds any exclusion of any quality from the essence of what thinks besides that which directly contradicts the nature of thought would be unwarranted. We also saw that Locke could find no contradiction between thought and solidity-they are different ideas, but in no way exclude each other. Thus, strictly on the grounds of avoiding contradiction, any exclusion of thought from the nominal essence of a solid substance, or any exclusion of solidity from the nominal essence of a thinking substance, would be unwarranted. But, we may also think of a thinking material being as being composed of two different nominal essences, if we so wish. In neither case do we peer beneath our constructed nominal essences into the underlying real essences, since real essences of substances are utterly beyond our comprehension. Locke has carefully composed his response to Stillingfleet in reference to this position on the limits of our knowledge of essences. Thus, the claim that the identity of souls requires souls to be solid takes the solidity of souls to render them as material substances. And since this claim is not about the real essence of souls, but rather about their nominal essence, Locke's explicit commitment to the possibility that matter thinks is consistent with his assertion that we do have an idea of souls as immaterial.

But, since the conclusion of the argument for the solidity of souls requires that the nominal essence of souls (or spiritual substances) include the idea of solidity for souls to have identity, why does Locke think we have, and are justified in having, an idea of immaterial spirit? When Locke discusses our ideas of substances as comprising only their nominal essences, he states that the idea of spirit is derived from reflection on the operations of the mind "without consideration of matter" (III.vi.11). In his chapter on our ideas of substances, when Locke characterized our ideas of body and spirit as being distinct, he finished his account by noting that he has presented "our complex ideas of Soul and Body, as contra-distinguished” (II.xxiii.22). These are the ideas of body and soul we happen to have. The ideas we form of thought and solidity exclude each other for no better reason than that we simply don't know how adequately to relate them causally (IV.iii.28-29). Careful thinking will keep us from concluding too much from our ignorance such as that thought and solidity cannot be subsumed in a single nominal essence, or are not in fact related in an underlying real essence beyond our comprehensions. Neither of these claims is within the scope of our knowledge.

\section{The Irrelevance of Solid Souls to Locke's Concerns about Identity}

So what does this mean for the choice between (2) and (2*)? The argument we've been considering says that thought and solidity ought to be related-that is, if souls have identity. Locke's exchange with Stillingfleet offers another significant perspective on the argument for the solidity of souls that bears directly on this point: Locke simply does not care whether souls meet any general conditions for identity. Stillingfleet senses this and argues that Locke's implication that spirit is a material substance eliminates the possibility of resurrection. But, Locke doesn't think that he needs an account of the identity of souls to allow for the possibility of resurrection. Locke has three accounts of identity: of substances, of organisms, and of persons. Locke's general criteria of identity underlies each kind of identity, but the specific criteria for identity of one sort does not account for the identity of things of another sort. Each particle of matter has its identity as a material substance. The identity of a person is determined by sameness of consciousness, such as in the relation one's present consciousness bears to some set of memories or to expectations concerning the future (II.xxvii.9). According to Locke, the continuous history of self-related consciousness need not belong to a single substance, spiritual or otherwise, and may belong to several (II.xxvii.10). Thus, the identity conditions for souls as substances do not underwrite the identity of a person. ${ }^{8}$ Solidity is therefore irrelevant to the identity of persons. Since the consequences of the general idea of identity and solidity on our idea of souls as substances neither help nor hinder Locke's account of personal identity, Locke has no pressing reason to draw explicitly the inference that souls are solid in his account of personal identity, and neither has he any reason to work out its implications. Given Locke's account of personal identity, the identity of souls is simply irrelevant to Locke's purposes. And, this is why Locke could reasonably remain ambivalent about developing what would give souls their proper identity conditions. ${ }^{9}$

Locke's treatment of the identity of living organisms is suggestive of the sort of place thinking matter would play in Locke's account of identity. The identity of an organism is, on Locke's account, distinct from the identity of each of its con-

\footnotetext{
${ }^{8}$ Only Locke's commitment to this view, rather than his defense of it, is relevant here.

${ }^{9}$ Of course, the remarks here about personal identity are sketchy and certainly merit fuller treatment elsewhere. Suffice it to say that an account of Lockean personal identity following up on these suggestions would restrict persons to being "modes" and not substances. This would put such an account at odds with the one advanced by Jonathan Bennett (2001: ch. 39) wherein Lockean persons are quasi-substantial. But it might be friendly to the account developed by Gideon Yaffe (2007), even though he refrains from invoking solidity as a universal criterion for the spatiotemporal exclusion of substances.
} 
stituent parts. Organisms are systems of particles of matter arranged so as to form the parts of the organism. Life is the continued functioning of those parts. Organisms constantly swap particles of matter with their surroundings without losing their identity as the same organism. So long as the parts of an organism serve their function within the organism, it matters not which particles compose those parts (II.xxvii.4-8). Thus the identity of an organism when considered as an organism is distinct from the identity of an organism as a lump of matter. Yet, the organism still is composed entirely of matter such that were the material parts of an organism to be annihilated, so would the organism. Thus organisms require that their parts be composed of material substances for the organism to have its identity as an organism.

Following Locke's thinking matter hypothesis, suppose thought, as well as the other powers of the soul, are powers exclusively of systems of matter fitly disposed to think. On this hypothesis the identity of that in us which thinks would, just as in the case of organisms, require there to be a parcel of solid material substance arranged in such a manner as to support God's superaddition of the power of thought. Thus on this hypothesis, the identity of a soul as a thing that thinks requires the soul to be a substance whose parts are solid. And just as in the case of organisms, the conditions for the identity of the thing that thinks, when considered as a thing that thinks, would not be the same as the conditions for the identity of its constituent solid parts as a mere collection of matter. According to the argument that souls are solid, the thinking matter hypothesis follows from our ideas of solidity and of the general conditions for identity, even if Locke didn't openly want or care to connect the two. Had he acknowledged this hypothesis as a consequence of his project, he wouldn't have to give up any of his other positions. Locke wouldn't even have had to abandon his claim that the immateriality of the soul is the more probable opinion, so long as such a claim is restricted to the unverifiable realm of real essences. Locke stakes his claim to the high probability of souls being immaterial as a consequence of his argument for the existence of God, and as a certainty expressed in scripture. ${ }^{10}$ It is at least a plausible suggestion that Locke has no independent philosophical support for his expressed confidence in the likelihood that souls are immaterial. As far as the philosophical implications of granting the hypothesis that matter thinks, Locke need only have restricted its scope to the nominal essence of thinking substance to ensure that his commitments could find support, or escape conflict, with his project in the Essay, and that is precisely what he did. It is in this sense that the solidity of souls is not at all a threat to Locke's further purposes concerning personal identity, while it conforms to his general account of the identity of substances, given his nominalism about essences.

\section{Evading the Solidity of Souls}

Simply attributing solidity to souls to account for their identity conditions is a novel suggestion. This can be seen better by examining some of the leading commentary on related topics in Locke scholarship concerning problems surrounding the identity of souls.

That Locke found it possible for thinking to be a power of solid substance is beyond controversy. The importance of this hypothesis to Locke's account of the limits of knowledge con-

${ }^{10}$ Letter, 36. cerning substance is non-negotiable for Edwin McCann. He examines the notion that thought could be superadded to matter as expressing Locke's commitment to mechanical corpusculareanism. McCann takes Locke's commitment to thinking matter as rising no higher than a possibility, albeit a vitally important possibility to be maintained in any tenable interpretation of his thought. For instance, McCann rejects an attempt to solve a conundrum about the nature of substance in general partially on the grounds that "it conflicts with one of Locke's central doctrines, that of the possibility of thinking matter" (1994: p. 80). For McCann, though, this remains just a possibility. $^{11}$

Nicholas Jolley takes a stronger stance than McCann on Locke's commitment to thinking matter by suggesting that Locke had a basis for a deeper commitment to materialism than he openly admits:

Locke agrees of course that materialism itself has its difficulties, but once these are recognized, there is no further puzzle posed by the supposition that body is intermittently the subject of mental states or properties. Locke of course does not explicitly draw this moral, but there are enough hints in the Essay to suggest that he wishes his readers to draw the moral for themselves (1999: p. 93).

Jolley verges on attributing the solidity of souls to Locke since he presents an inference to materialism from Locke's published works that Locke refrains from drawing himself. ${ }^{12}$ However, Jolley does not connect this implicit materialism to Locke's general criteria for the identity of substances. Neither does Jolley address at all Locke's claims that souls be spatiotemporally distinguished from other substances.

The motivation for moving beyond the attenuated position ascribed to Locke by McCann and Jolley arises from some difficulties in Locke's treatment of identity. McCann urges a general account of identity that takes spatiotemporal continuity as comprising the basis for the identity of any simple substance including souls (1987: p. 59). McCann develops at length the meaning of this principle as it applies to atoms-making much use of solidity (and indivisibility) as the basis for determining the continued spatiotemporal existence of particles of matter:

As bodies, or extended solid substances, atoms by their solidity exclude all other bodies or material things from the volume of space which, thanks to their extension, they at any time occupy (60).

While he subjects the identity of atoms to extensive inquiry, McCann abandons the question of what determines the spatio-

\footnotetext{
${ }^{11}$ See also McCann (2001: pp. 92-93) and McCann (2007: pp. 177-185). Michael Ayers (1991) opposes many of McCann's positions, but agrees that the possibility of thinking matter remains merely a possibility (Vol. 2, p. 149). ${ }^{12}$ Jolley also presents Locke's position as suffering from tensions arising from the formulation of his hypothesis of thinking matter. Jolley wonders why matter would have to be "fitly disposed" to receive a quality that God would superadd to it (1999: pp. 95-99). He thinks a fit disposition for superaddition would render superfluous the need for God to superadd a quality since a fit disposition would itself be the underlying sufficient condition for the quality to be superadded. But contrary to Jolley, if we take "fitly disposed" simply to mean "determined by God to have some quality superadded," it is difficult to find a conflict here. Fit disposition could require the absence of a quality that, given all the other qualities a thing has, is flatly inconsistent with the other quality God superadds. Given the absence of some quality, God's superaddition of some other quality to those qualities would yield a total set of qualities including no contradictory qualities. Nevertheless, while Jolley admits that Locke's position appears to be consistent, he is reticent to say that Locke is not confused in allowing the possibility that thought be superadded to matter (98).
} 
temporal identity of souls. ${ }^{13}$ McCann thus holds that though the same general principle determines the identity of atoms as well as finite intelligences, Locke has the apparatus to explain the application of the principle to simple material substances, but neglects to do so for spirits. McCann refrains from calling that common principle "solidity", but nor does he say why solidity is not that principle. ${ }^{14}$

One commentator unafraid of explicitly invoking solidity to account for the identity of souls is Thomas Lennon. Inquiring into Locke's atomism, Lennon lands on the problem concerning the application of Locke's general criteria for identity to both bodies and souls:

What excludes every other body from the place-time of a body is its solidity, or the impenetrability resulting from its solidity. But what is it that excludes another spirit from the place of a spirit? Nothing from what I can make out in Locke. Only if there is but one sort of being, namely, solid being, can Locke's principle of individuation be made to work. Creation of any sort, then, is the creation of solidity (1992: p. 310).

This passage seems to be a powerful endorsement of the argument for the solidity of souls. Like Jolley after him, Lennon argued that Locke's rejection of the Cartesian thesis that the mind always thinks bears a strong affinity with the thinking matter hypothesis. Lennon doesn't carry this argument nearly as far as Jolley since Lennon holds the connection between the two positions to be a mere affinity. And though Lennon presents an interesting and convincing case for Locke's materialist tendencies, if not his outright materialism, the bulk of his textual evidence from Locke's own hand concerns the books Locke read and commented on, as well as other unpublished errata. As far as Locke's published commitments go, Lennon maintains the softened position, largely in accord with McCann, that Locke only allowed for the possibility of thinking matter. The argument for the solidity of souls nonetheless very strongly accords with Lennon's thesis that the conditions for the use of the relation of identity to individuate simple substances apply univocally to finite bodies and finite spirits.

\section{Conclusion}

We have seen agreement among leading commentators that Locke has endorsed the possibility of holding one substance both to be solid and to bear the power of thought. Those who focus on the general conditions of identity note that Locke has not provided any account of the identity of finite spirits, while he has provided solidity as a means of doing so for finite bodies. Yet, they also acknowledge that Locke takes exclusion from place to be the principle of identity for both body and soul. Those who delve into Locke's mechanism further discover that Locke treats solidity as the filling of space to exclude others from occupying it. Locke also hold that solidity and thought

\footnotetext{
${ }^{13}$ M. R. Ayers (1991) agrees with McCann that spatiotemporal continuity is the basis for the principle of individuation for both matter and spirit, but adds that "Locke did not explain what it is for a finite intelligence to occupy a place” (Vol. 2, p. 209).

${ }^{14}$ Martha Bolton (1994) agrees with McCann and Ayers that Locke allows a possibility of thinking matter and considers souls to have spatial locations, while also refraining from attributing solidity to souls as the principle allowing them their spatial location. Her analysis of the identity of body does not explicitly refer to solidity, but she does use the same texts I considered above in my determination that solidity is the idea required for spatiotemporal exclusion. Yet Bolton remarks that "[f]inite intelligences are also simple substances but nothing is said about their identity” (114; see also 124-125).
}

can coexist as qualities in one substance. So why be coy about the very notion in Locke's suite of ideas that would quite effectively account for the identity of souls? The identity conditions for souls thus ought to be regarded as relying upon the idea of solidity. It unifies his discussions of substances and essences in his replies to Stillingfleet. And, it serves a vital interpretive role in unifying Locke's general account of identity, a central notion in perhaps his most novel and interesting lasting contribution to philosophy, his account of personal identity.

\section{Acknowledgements}

Portions of this paper were presented at conferences at Claremont Graduate University, University of California, Irvine, and University of Turku, Finland. I owe special thanks to Kurt Smith, Patricia Easton, Olli Koistinen, Thomas Lennon, Edwin McCann, Alan Nelson and Nicholas Jolley, and to the anonymous reviewers for this journal for their helpful comments and suggestions in the preparation of this paper.

\section{REFERENCES}

Ayers, M. (1991). Locke: Epistemology and ontology (2 vols). New York: Routledge.

Bennett, J. (2001). Learning from six philosophers (Vol. 2). New York: Oxford University Press.

Bolton, M. B. (1994). Locke on identity: The scheme of simple and compounded things. In K. F. Barber, \& J. J. E. Gracia (Eds.), Individuation and identity in early modern philosophy (pp. 103-132). Albany: SUNY Press.

Jolley, N. (1999). Locke: His philosophical thought. Oxford: Oxford University Press.

Lennon, T. M. (1993). The battle of the gods and giants. Princeton: Princeton University Press.

Locke, J. (1979). An essay concerning human understanding. In P. H. Nidditch (Ed.), Oxford: Oxford University Press.

Locke, J. (1823). Letter to the right reverend Edward, lord bishop of Worcester. And second reply to Edward, bishop of Worcester. The works of John Locke (12th ed., Vol. 4). Aalen: Scientia.

McCann, E. (1987). Locke on identity: Matter, life, and consciousness. Archiv für Geschichte der Philosophie, 69, 54-77. doi:10.1515/agph.1987.69.1.54

McCann, E. (1994). Locke's philosophy of body. In V. Chappell (Ed.), The cambridge companion to locke (pp. 56-88). New York: Cambridge University Press. doi:10.1017/CCOL0521383714.004

McCann, E. (2001). Locke's theory of substance under attack! Philosophical studies, 106, 87-105. doi:10.1023/A:1013162304000

McCann, E. (2007). Locke on substance. In L. Newman (Ed.), The Cambridge companion to Locke's “Essay concerning human understanding” (pp. 157-191). New York: Cambridge University Press. doi:10.1017/CCOL0521834333.007

Yaffe, G. N. (2007). Locke on ideas of identity and diversity. In L. Newman (Ed.), The Cambridge companion to Locke's "Essay concerning human understanding” (pp. 192-230). New York: Cambridge University Press. doi:10.1017/CCOL0521834333.008 